Abstract-Cobia (Rachycentron cana$d u m$ ) is a pelagic, migratory species with a transoceanic distribution in tropical and subtropical waters. Recreational fishing pressure on Cobia in the United States has increased substantially during the last decade, especially in areas of its annual inshore aggregations, making this species potentially susceptible to overfishing. Although Cobia along the Atlantic and Gulf coasts of the southeastern United States are currently managed as a single fishery, the genetic composition of Cobias in these areas is unclear. On the basis of a robust microsatellite data set from collections along the U.S. Atlantic coast (2008-09), offshore groups were genetically homogenous. However, the 2 sampled inshore aggregations (South Carolina and Virginia) were genetically distinct from each other, as well as from the offshore group. The recapture of stocked fish within their release estuary 2 years after release indicates that some degree of estuarine fidelity occurs within these inshore aggregations and supports the detection of their unique genetic structure at the population level. These results complement the observed high site fidelity of Cobias in South Carolina and support a recent study that confirms that Cobia spawn in the inshore aggregations. Our increased understanding of Cobia life history will be beneficial for determining the appropriate scale of fishery management for Cobia.

Manuscript submitted 25 April 2012. Manuscript accepted 6 November 2013. Fish. Bull. 112:24-35 (2014).

doi: 10.7755/FB.112.1.2

The views and opinions expressed or implied in this article are those of the author (or authors) and do not necesarily reflect the position of the National Marine Fisheries Service, NOAA.

\title{
Population genetics of Cobia (Rachycentron canadum): implications for fishery management along the coast of the southeastern United States
}

\author{
Tanya L. Darden (contact author) \\ Matthew J. Walker \\ Karl Brenkert \\ Justin R. Yost \\ Michael R. Denson \\ Email address for contact author: dardent@dnr.sc.gov \\ South Carolina Department of Natural Resources \\ Marine Resources Research Institute \\ 331 Fort Johnson Road \\ Charleston, South Carolina 29412
}

Cobia (Rachycentron canadum), belonging to the monotypic family Rachycentridae (Actinopterygii: Perciformes), is a large, pelagic, migratory species distributed throughout tropical and subtropical waters of the Atlantic, Indian, and western $\mathrm{Pa}$ cific oceans (Shaffer and Nakamura, 1989). The species is highly prized by both recreational fisheries and aquaculture producers as excellent table fare. Within the United States, this recreationally and commercially important fish species occurs along the southeastern Atlantic and Gulf of Mexico coasts. Cobia has historically been managed by the South Atlantic Fishery Management Council and Gulf of Mexico Fishery Management Council as a single reproductive stock on the basis of minimal data from tag and recapture research and mitochondrial fragment analysis (Hrincevich, 1993). Most early life history information on Cobia comes from aquaculture research, and little is known about its natural life history.

In the spring and early summer months, Cobias in the western North Atlantic are thought to migrate with warming waters from Florida to the Chesapeake Bay (Shaffer and Nakamura, 1989). During this putative northward migration, Cobias enter high salinity bays and estuar- ies, including Port Royal Sound and St. Helena Sound in South Carolina (SC), Pamlico Sound in North Carolina (NC; Smith, 1995), and the Chesapeake Bay (Shaffer and Nakamura, 1989). Cobias have been reported to spawn from April to September (Smith, 1995; Lotz et al., 1996; Burns et al.; ${ }^{1}$ Brown-Peterson et al., 2001). Regional peaks in spawning correlate with their proposed annual migration from Florida to Massachusetts, occurring in May along the SC coast (Shaffer and Nakamura, 1989; Burns et al.1), June in NC (Smith, 1995), and during June and July in the Chesapeake Bay region (Joseph et al., 1964).

One aspect of Cobia biology that has only recently been investigated is their annual inshore aggregations that occur in high-salinity estuaries. The nature of these aggregations has been hypothesized to be associated with either feeding or reproduction (Joseph et al., 1964; Richards, 1967; Hassler and Rainville, 1975; Smith, 1995; Lotz et al., 1996; Burns et al. ${ }^{1}$ ),

1 Burns, K., C. Neidig, J. Lotz, and R. Overstreet. 1998. Cobia (Rachycentron canadum) stock assessment study in the Gulf of Mexico and in the south Atlantic. Mote Marine Laboratory Technical Report No. 571, 108 p. [Available from Mote Marine Laboratory, 1600 Thompson Parkway, Sarasota, FL 342236.] 
and only recently has research verified the reproductive function of these aggregations through documentation of the presence of eggs, newly hatched Cobia larvae and reproductively mature females within the Port Royal Sound and St. Helena Sound estuaries in SC (Lefebvre and Denson, 2012). Therefore, the limited understanding of Cobia life history provides conflicting expectations regarding the genetic structure at the population level (hereafter 'population genetic structure'). On one hand, their pelagic nature and transoceanic distribution would indicate a high potential for long distance movement and gene flow (i.e., no genetic structure expected); conversely, the presence of sitespecific spawning aggregations might indicate a low potential for gene flow (i.e., genetic structure expected). Because the foundation for effective management of marine fishes is built upon the determination of biological population segments, a better understanding of Cobia biology and population genetic structure over a broad geographic area is necessary.

Commercial and recreational U.S. harvests of Cobia along the middle and south Atlantic have been highly variable over time, but generally have been increasing since 1980 (Atlantic Coastal Cooperative Statistics Program, http://www.ACCSP.org). Concurrently, recreational fishing pressure on Cobias has increased substantially in the last decade, especially in areas where they exhibit annual inshore aggregations (SC, VA) and this pressure has made them susceptible to overfishing during a potentially critical life stage. In these areas, fishing tournaments focused solely on Cobias are popular (McGlade, 2007) and "catch and release" is the exception rather than the rule. Therefore, with continued increases in human populations in coastal areas and subsequent increased fishing pressure on both offshore and inshore coastal finfish populations, the South Carolina Department of Natural Resources (SCDNR) began evaluating the feasibility of stocking Cobias as a management option. In 2001, the SCDNR began collecting Cobias from the wild, developing broodstock conditioning regimes, spawning broodstock in the laboratory, and producing juveniles for aquaculture development and stock enhancement (Weirich et al., 2004). In addition, efforts were made to collect life history information (spawning, growth, and genetics) of the wild populations during seasonal migrations. Externally tagged, cultured fish were also released into the estuary from which the wild broodstock had been collected as a fisheries research tool to monitor movement, determine appropriate tag types, identify site fidelity, determine growth rates, and verify annulus formation in otoliths.

In 2007, shortly after Pruett et al. (2005) and Renshaw et al. (2006) published microsatellite loci for Cobia, we optimized 3 multiplexed microsatellite panels of 10 loci to use as genetic tags for stocked fish and population genetic analyses. Although the genetic tools were not ready for use until 2007, fin clips were available from all hatchery broodstock used in the program between 2004 and 2007. Here, we present population genetic data on the basis of the 2008 and 2009 collections and recapture data for Cobias collected from south Atlantic coastal waters. Specifically, our goals are to characterize the genetic structure of the Cobia population along the southeast Atlantic coast of the United States; determine if population genetic structure is detectable on the basis of movement patterns; document if any degree of estuarine fidelity occurs in Cobias; and evaluate whether genetic data support the reproductive role of their seasonal inshore aggregations. Because of the general lack of knowledge of their biology, we used a multidisciplinary effort over a broad geographical area to address current obstacles facing management of Cobia.

\section{Materials and methods}

\section{Broodstock and production}

Broodstock used for the production of all stocked fish was collected from the Port Royal Sound estuary (Fig. 1); the broodstock pool ranged from 9 to 16 individuals per year (Table 1). Spawning occurred at the Marine Resources Research Institute in Charleston, SC, and Waddell Mariculture Center in Bluffton, SC, and all rearing occurred in outdoor nursery ponds at the Waddell Mariculture Center. Relatively small numbers of fish have been produced and released since 2004; 2007 represented the largest release with $\sim 54,000$ fish (Table 1). All year classes are identifiable with distinct genetic tags (as described later). Genetic tags offer a noninvasive, permanent approach that can be applied to all sizes of fish, including larvae, and they are identifiable through parentage analysis. Small juveniles were released at approximately 30 days after hatching, large juveniles at approximately 90 days after hatching, and yearlings the following spring. Yearlings from the 2004 and 2005 year classes were also individually tagged with external tags before release. Either an $89-\mathrm{mm}$ or 127-mm nylon dart tag (Hallprint Pty Ltd., ${ }^{2}$ Hindmarsh Valley, Australia) was inserted into the dorsal musculature. All Cobia releases occurred in the Port Royal Sound at the Trask boat landing in Bluffton, SC.

\section{Sampling}

Anal-fin tissue samples were collected from adult Cobias at fishing tournaments, filleted fish carcasses donated to SCDNR's freezer program by cooperating anglers, and fish collected by SCDNR personnel during the spawning seasons of 2008 and 2009 (April-July). Because Cobia is a federally managed species with a minimum size limit of $83.8 \mathrm{~cm}$ fork length $(\sim 93.8 \mathrm{~cm}$ $\mathrm{TL}$ ), the species is not expected to recruit to the fishing

\footnotetext{
2 Mention of trade names or commercial companies is for identification purposes only and does not imply endorsement by the National Marine Fisheries Service, NOAA.
} 


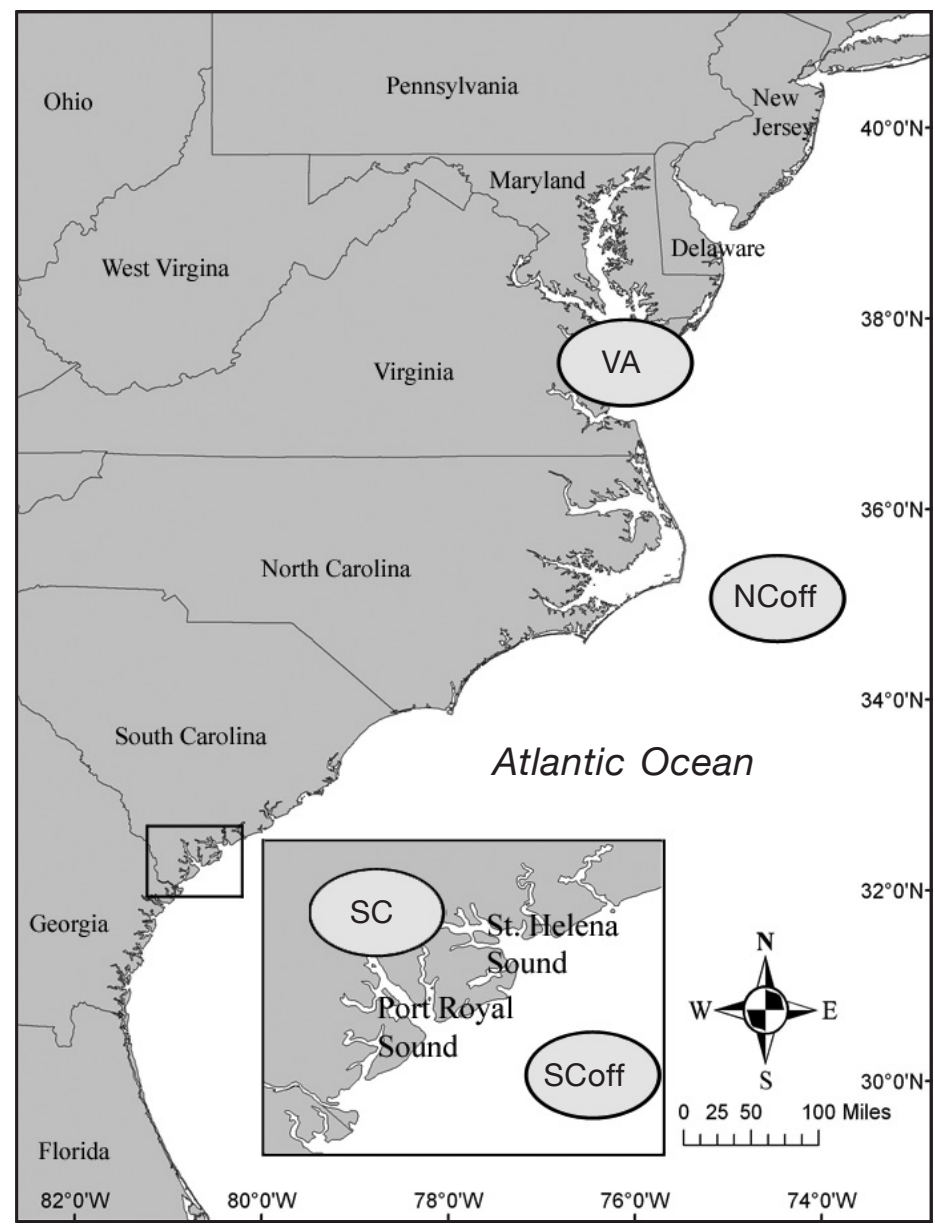

Figure 1

Map of sampling locations for Cobias (Rachycentron canadum) from 2008 to 2009 along the Atlantic coast of the southeastern United States. Locations included inshore Virginia (VA), offshore North Carolina $\left(\mathrm{NC}_{\mathrm{Off}}\right)$, inshore South Carolina $(\mathrm{SC})$, and offshore South Carolina $\left(\mathrm{SC}_{\mathrm{Off}}\right)$.

gear until 2-3 years of age, thus creating a potential lag in recruitment and subsequent genetic identification of up to 3 years. Collection locations were provided for each specimen by participating anglers. Our 2008 collection comprised a broader geographic scope than that of 2009. In 2008, we obtained 488 samples from Virginia (VA), NC, and SC; whereas, our 2009 collection comprised 290 samples from only NC and SC. Although our SC-collected sample sizes were high in both years (349 and 234), specific capture location details were missing from the associated collection data for many samples. As described later, samples were included in each analysis only if appropriate associated data were available (Table 2). Collections during both years were confined to limited areas; the southern portion of the state of SC, the offshore area of the Albemarle Sound in NC, and the vicinity of Chesapeake Bay in VA (Fig. 1). Collected fin tissue was stored at room temperature in a solution for the stabilization of DNA and cell lysis-a solution made of $8 \mathrm{M}$ urea, $1 \%$ sarkosyl, $20 \mathrm{mM}$ sodium phosphate, and $1 \mathrm{mM}$ EDTA. Externally tagged Cobia were recaptured during the previously described sample collections as well as through additional tag reporting by recreational anglers during both years.

\section{Molecular protocols}

Total DNA was isolated from the sarkosyl-urea solution and tissue lysate by using the Agencourt SprintPrep plasmid purification system (Beckman Coulter, Inc., Brea, MA) according to the manufacturer's instructions. Ten microsatellite loci were amplified in 3 multiplexed polymerase chain reactions. Each reaction contained $0.2 \mathrm{mM}$ dNTPs, $1 \times$ HotMaster buffer with $2.5 \mathrm{mM} \mathrm{Mg}^{2+}, 0.025$ units Hotmaster Taq DNA Polymerase (5 Prime, Inc., Gaithersburg, MD), and $0.5 \mathrm{mM} \mathrm{MgCl}_{2}, 0.20$ $\mathrm{mg} / \mathrm{mL} \mathrm{BSA}, 0.3 \mu \mathrm{M}$ forward and reverse primers, and $1 \mu \mathrm{L}$ of 1:10 diluted DNA isolate. All forward primers were labeled with WellRED florescent dyes (Beckman Coulter, Inc.); individual primer concentrations differed for each locus (Table 3). All amplifications were performed in $11-\mu \mathrm{L}$ reaction volumes in iCycler systems (Bio-Rad Laboratories, Hercules, CA) by using a $60^{\circ} \mathrm{C}$ touchdown protocol (modified from Renshaw et al., 2006) that consisted of 3 steps after initial denaturation at $94^{\circ} \mathrm{C}$ for $2 \mathrm{~min}$. Step 1 included 7 cycles of $94^{\circ} \mathrm{C}$ for $30 \mathrm{~s}, 60^{\circ} \mathrm{C}$ for $1 \mathrm{~min}$ and $64^{\circ} \mathrm{C}$ for $2 \mathrm{~min}$. Step 2 included 7 cycles of $94^{\circ} \mathrm{C}$ for $30 \mathrm{~s}, 57^{\circ} \mathrm{C}$ for 1 min and $64^{\circ} \mathrm{C}$ for $2 \mathrm{~min}$. Step 3 included twenty cycles of $94^{\circ} \mathrm{C}$ for $30 \mathrm{~s}, 54^{\circ} \mathrm{C}$ for $1 \mathrm{~min}$ and $64^{\circ} \mathrm{C}$ for $2 \mathrm{~min}$, followed by a final extension at $64^{\circ} \mathrm{C}$ for $60 \mathrm{~min}$. The protocol includes substantial decreases in extension times from that of Renshaw et al. (2006) to shorten the overall length of the protocol. All amplifications were run with 2 negative controls. Reaction products and size standards (GenomeLab DNA Size standard Kit 400; Beckman Coulter, Inc.) were separated with a CEQ8000 automated DNA sequencer (Beckman Coulter, Inc.), and fragment size analysis was performed with the CEQ8000 software package. All chromatograms were scored manually, and genotypes were verified independently by a second reader. Approximately $10 \%$ of the samples were regenotyped to provide validation.

\section{Marker statistics and parentage analysis}

The sample data pooled over collection years were used to test all loci for adherence to Hardy-Weinberg equilibrium (HWE), linkage disequilibrium, and the presence of genotyping artifacts at each collection locality separately (i.e., for SC samples, only those with known collection information were included). Examinations for departures from HWE and for linkage disequilibrium between loci pairs were performed in the program Ar- 


\section{Table 1}

Summary of data for tagged and released cultured Cobia (Rachycentron canadum) in South Carolina by release year, with number of broodstock used for production, size at release, mean total length (TL), and number of individuals released. Small juveniles were released during the summer of the production year, large juveniles were released during the fall of the production year, and yearlings were released the following spring.

\begin{tabular}{|c|c|c|c|c|}
\hline $\begin{array}{l}\text { Year } \\
\text { class }\end{array}$ & $\begin{array}{l}\text { Number of } \\
\text { broodstock }\end{array}$ & $\begin{array}{l}\text { Size at } \\
\text { release }\end{array}$ & $\begin{array}{l}\text { Mean TL } \\
\quad(\mathrm{mm})\end{array}$ & $\begin{array}{l}\text { Number } \\
\text { released }\end{array}$ \\
\hline \multirow[t]{3}{*}{2004} & 8 & Small juveniles & 97 & 1128 \\
\hline & & Large juveniles & 328 & 679 \\
\hline & & Yearlings & 496 & 93 \\
\hline \multirow[t]{3}{*}{2005} & 7 & Small juveniles & 56 & 3200 \\
\hline & & Large juveniles & 230 & 516 \\
\hline & & Yearlings & 545 & 385 \\
\hline \multirow[t]{3}{*}{2007} & 16 & Small juveniles & 82 & 53,264 \\
\hline & & Large juveniles & 250 & 409 \\
\hline & & Yearlings & 541 & 59 \\
\hline \multirow[t]{2}{*}{2008} & 11 & Large juveniles & 249 & 2000 \\
\hline & & Yearlings & 530 & 54 \\
\hline 2009 & 9 & Large juveniles & 235 & 1392 \\
\hline
\end{tabular}

lequin 3.11 (Excoffier et al., 2005) with default parameters. The frequencies of potential null alleles at each locus were estimated in Cervus, vers. 3.0 (Kalinowski et al., 2007). Significance levels for all simultaneous analyses were adjusted with a sequential Bonferroni correction (Rice, 1989).

To confirm the utility of the marker suite for genetic evaluation and parentage analysis (i.e., identification of genetic tags), loci were examined for genetic diversity and polymorphism, for the ability to distinguish between related individuals, and for adherence to the principles of Mendelian inheritance. Basic molecular diversity indices, including number of alleles per locus $\left(\mathrm{N}_{\mathrm{a}}\right)$, and allelic size range were calculated for each locus through the use of Arlequin software. Cervus was used to estimate the average parent-pair and identify nonexclusion probabilities for the loci suite-indices that measure the probability that a set of markers will match erroneous parents to offspring and the probability that a set of markers will not be able to distinguish between related individuals, respectively.

To determine whether hatchery individuals contributed to the southeastern Atlantic Cobia populations, parentage analyses were conducted that incorporated all field samples and hatchery broodstock. Simulations $(n=5)$ for the "sexes known" parentage analysis in Cervus consisted of 10,000 offspring and 8 candidate parent pairs per year $(100 \%$ sampled) with allele frequencies generated from all Cobia samples. Critical delta values were determined with $95 \%$ confidence for the relaxed criteria and with $99 \%$ confidence for the strict criteria. All parentage analyses were run with the modal simulation file. Although all project samples genotyped at 8 or more loci were subjected to parentage analyses, contribution calculations were limited to only those sampled within the stocking area. The percentage of hatchery contribution is reported as $\left[S(W+S)^{-1}\right] 100$, where $S$ is the number of stocked individuals and $W$ is the number of wild individuals as designated by Cervus at the strict confidence level because no additional offspring were identified with the relaxed criteria. Contribution is reported in terms of both population (all samples) and year class (on the basis of known-age fish). All sampled fish identified as being of hatchery origin were removed from population structure analyses. Identity analyses (as implemented in Cervus) were also conducted to compare the 2008 and 2009 samples in order to identify recaptures of both hatchery and wild individuals.

For the Mendelian inheritance tests, 25 offspring from two parental families of the 2007 hatchery production year were compared with the 2007 broodstock by using Probmax, vers. 3.1 parentage analysis software (Danzmann, 1997) to verify the contributing parent pairs. The genotypes of the contributing parents were merged into a single file and imported into FAP 3.6 (Taggart, 2007), to generate all the possible progeny genotypes associated with these parental crosses. A chi-square analysis $\left(\chi^{2}\right)$ was performed to compare the observed genotypic frequencies from the progeny data set with the expected genotypic frequencies from FAP.

\section{Population genetic analyses}

For all population genetic analyses, samples were partitioned into those from the inshore aggregations (defined as being captured landward of the barrier island, either along the coast or in the estuary) and

\section{Table 2}

Distribution of Cobia (Rachycentron canadum) collected during 2008 and 2009 with a known collection location that were included in the analyses of population genetic structure. Dashes indicate locations where no sampling occurred.

\begin{tabular}{lrr}
\hline Location & 2008 & 2009 \\
\hline Virginia inshore & 35 & - \\
North Carolina offshore & 90 & 56 \\
South Carolina inshore & 103 & 109 \\
South Carolina offshore & 71 & 55 \\
& & \\
\hline
\end{tabular}




\section{Table 3}

Multiplex group (panel), locus, fluorescent label (dye), repeat motif, and primer concentrations ( $\mu \mathrm{M})$ for polymerase chain reactions for 10 Cobia-specific microsatellite loci (modified from Renshaw et al., 2006). Summary statistics for each locus were based on the total combined project data set. $n=$ sample size, $\mathrm{N}_{\mathrm{A}}=$ number of alleles, $\mathrm{A}=$ allelic size range.

\begin{tabular}{rllccrrr}
\hline Panel & Locus & WellRED dye & Repeat motif & [Primer $]$ & $n$ & $\mathrm{~N}_{\mathrm{A}}$ & A \\
\hline \multirow{2}{*}{1} & Rca1-H10 & D2 & CA & 0.10 & 514 & 11 & $116-138$ \\
& Rca1-A04 & D4 & $(\text { CA })_{9}(\text { CACT })_{4}$ & 0.05 & 516 & 11 & $180-210$ \\
\multirow{2}{*}{2} & Rca1B-E02 & D4 & CT & 0.15 & 516 & 7 & $301-317$ \\
& Rca1-A11 & D4 & GT & 0.05 & 513 & 22 & $166-212$ \\
& Rca1B-H09 & D2 & GATA & 0.09 & 516 & 17 & $169-233$ \\
& Rca1B-E08A & D3 & CA & 0.11 & 516 & 12 & $201-247$ \\
3 & Rca1B-C06 & D4 & GATA & 0.05 & 514 & 22 & $329-417$ \\
& Rca1B-D10 & D3 & CTAT & 0.13 & 515 & 28 & $132-260$ \\
& Rca1-E11 & D2 & CA & 0.04 & 518 & 6 & $167-181$ \\
& Rca1-C04 & D4 & GT & 0.13 & 516 & 17 & $221-261$ \\
\hline
\end{tabular}

those from offshore areas (defined as captured seaward of the barrier islands, mostly near wrecks or reefs); samples without sufficient collection details for assignment were excluded (Table 2). Samples collected from the Port Royal Sound and St. Helena Sound estuaries were pooled for the SC inshore location because tagged fish recaptured after being at liberty for only a short period indicated substantial movement between these adjacent and connected estuaries.

An exact $G$-test with Markov Chain permutations, as implemented in Genepop, vers. 4.0.10 (Raymond and Rousset, 1995), was used to test for pairwise differences in genotypic distributions among collection locations during each collection year. Markov chain parameters included 10,000 dememorizations, 100 batches, and 5000 iterations per batch. Part of the analyses of genetic structure used $R_{\mathrm{ST}}$ statistics, which incorporate a stepwise mutation model to estimate population differentiation and are analogous to $F_{\mathrm{ST}}$ statistics (Slatkin, 1995). Pairwise, hierarchical $R_{\mathrm{ST}}$ statistics were calculated and an analysis of molecular variance (AMOVA) was conducted-as implemented in Arlequin with 10,000 iterations to determine the degree of genetic structuring occurring among states. Structure, vers. 2.3 (Pritchard et al., 2000) also was used to infer subpopulations through a clustering-based algorithm. The Admixture with LocPrior model was implemented, including runs of $k=1-4$ for the 2008 collection and $k=1-3$ for the 2009 collection. All models incorporated 10,000 iterations and a 10,000 burn-in period and were replicated in triplicate. Pairwise comparisons of genotypic distributions and $R_{\mathrm{ST}}$ calculations between 2008 and 2009 collection locations were conducted as described previously to determine the degree of temporal genetic stability of Cobia populations along the southeast- ern U.S. Atlantic coast as well as to validate temporal pooling of samples for genetic characterization of detected populations. Populations were characterized genetically by calculation of the average number of alleles per locus $\left(\mathrm{N}_{\mathrm{a}}\right)$, observed heterozygosity $\left(H_{\mathrm{O}}\right)$, genetic diversity $\left(H_{\mathrm{E}}\right.$; Nei, 1987), and inbreeding coefficients $\left(F_{\text {IS }}\right)$ by using Arlequin and Genepop.

\section{Results}

For this project, 764 individuals were genotyped. For both collection years, high proportions of loci were able to be scored unambiguously with high repeatability $(>99 \%)$, resulting in low levels of missing data (2008: 1.6\%; 2009: 0\%). Genetic data from 519 samples were used for all loci testing (Table 2). All loci at all collection locations were found to be in HWE $(P>0.05)$, with no evidence of null alleles (frequency<0.06) and no indication of linkage disequilibrium between any loci (critical $P$-value after Bonferonni=0.001). All 10 loci were polymorphic with allelic richness ranging from 6 to 28 (mean: 15.4 alleles per locus) (Table 3 ). The $\chi^{2}$ test for comparing hatchery broodstock and offspring indicated that all loci are inherited in a Mendelian fashion (Table 4).

The loci suite provides an average nonexclusion parent-pair probability of $1.3 \times 10^{-7}$ and average nonexclusion identity probability of $5.8 \times 10^{-12}$, signifying that the possibility of misassignment of parentage in the parentage analysis is substantially less than $0.01 \%$ and individuals can be identified confidently. Therefore, on the basis of initial tests, our suite of microsatellite markers is valuable for characterization of population genetic diversity and genetic structure, as well as for parentage analysis because the loci are genetically 


\section{Table 4}

Mendelian inheritance statistics for two independent families of Cobia (Rachycentron canadum): chi-square $\left(\chi^{2}\right)$ values, degrees of freedom (df), and $P$-values at each of the 10 Cobia-specific microsatellite loci. For two loci in family 2 , both parents were homozygous for different alleles and all offspring were fixed heterozygotes, as expected (an asterisk indicates each of these loci).

\begin{tabular}{|c|c|c|c|c|c|c|}
\hline \multirow[b]{2}{*}{ Locus } & \multicolumn{3}{|c|}{ Family 1} & \multicolumn{3}{|c|}{ Family 2} \\
\hline & $\chi^{2}$ & $\mathrm{df}$ & $P$-value & $\chi^{2}$ & $\mathrm{df}$ & $P$-value \\
\hline Rca1-H10 & 2.27 & 1 & 0.131 & 1.33 & 1 & 0.248 \\
\hline Rca1-A04 & 0.09 & 1 & 0.764 & 0.50 & 2 & 0.778 \\
\hline Rca1B-E02 & 2.27 & 1 & 0.131 & 0.00 & 1 & 1.000 \\
\hline Rca1-A11 & 4.40 & 3 & 0.221 & 1.00 & 1 & 0.317 \\
\hline Rca1B-H09 & 0.00 & 1 & 1.000 & 5.33 & 2 & 0.069 \\
\hline Rca1B-E08A & 1.80 & 2 & 0.406 & $*$ & - & - \\
\hline Rca1B-C06 & 3.00 & 3 & 0.391 & 2.45 & 3 & 0.484 \\
\hline Rca1B-D10 & 1.00 & 3 & 0.801 & 0.40 & 1 & 0.527 \\
\hline Rca1-E11 & 1.22 & 2 & 0.543 & $*$ & - & - \\
\hline Rca1-C04 & 0.00 & 1 & 1.000 & 3.89 & 3 & 0.273 \\
\hline
\end{tabular}

varied, adhere to the expectations of Mendelian inheritance, distinguish between related individuals, and correctly match offspring to their parents with a high degree of confidence.

\section{Movement and estuarine fidelity}

No fish collected outside of SC were genetically identified as SC-stocked fish; therefore our evaluation of hatchery contribution represents their contribution to SC Cobia populations. Parentage analysis of 341 samples identified two fish in the SC 2008 collections that were both originally stocked in 2004 into Port Royal Sound. On the basis of otolith aging, 174 fish from the 2004 year class (YC) were present in the SC 2008 collections. Therefore, the 2004 stocked fish made a $1.1 \%$ contribution to the SC $2004 \mathrm{YC}$ of Cobias. A large number of the SC 2008 samples, including the two recaptured stocked fish, were missing specific collection details. Without these details, we were unable to assign samples to inshore and offshore groups. Therefore, the year-class contribution was estimated on the basis of all SC samples-an assessment that likely underestimated the true contribution. From the 2008 samples, the 2004 YC stocked fish represented $0.6 \%$ of all SCcollected samples.

From the 2009 collections ( $n=232$ ), 11 stocked fish were identified, all from the $2007 \mathrm{YC}$ small juvenile stockings in Port Royal Sound. Thirteen 2007 YC fish were identified in the 2009 collections, resulting in an $84.6 \%$ contribution of stocked fish to the SC Cobia 2007 $\mathrm{YC}$ and a $4.7 \%$ contribution to the overall SC popula- tion of sampled Cobias. Of the identified stocked fish, 8 were recaptured within the Port Royal Sound estuary, and the remaining 3 recaptured stocked fish did not have sufficient collection information for group assignment. In addition to the recapture of stocked fish in their release estuary, one wild fish was recaptured within the Port Royal Sound estuary in multiple years (this finding was based on genetic identity analysessee previous section). No wild recaptures were detected among different collection locations. Although these recaptures were represented by low sample sizes, the pattern of site fidelity among all recapture groups was consistent.

For external tag recaptures, 7 tag returns were reported from the $2004 \mathrm{YC}$ of stocked yearling Cobias (93 originally stocked; Table 5). Within 32 days after release (mean of 25 days at large), 5 of the fish were recaptured, and 1 fish was recaptured later that summer; however, the remaining fish was recaptured the following spring after 370 days at large. All tag returns of $2004 \mathrm{YC}$ fish were recaptured within the SC inshore area. From the 2005 YC fish that were stocked with external tags $(n=385), 58$ were recaptured over a 3 -year period. Two of these recaptures were reported with no collection information. Within 40 days after release (mean of 17 days at large), 44 of the 2005 YC fish were recaptured, and all of the fish that were reported with location information were recaptured within the SC inshore area. Of the remaining fish, 7 were recaptured within the SC inshore area 2-3 years after their stocking during the spawning season; these fish had a mean of 813 days at large. The final 5 fish were recaptured 


\section{Table 5}

Summary of recapture information for Cobia (Rachycentron canadum) released in South Carolina with external tags. Distance values represent the distance from the specific stocking location in Port Royal Sound to the recapture location. Calibogue Sound is a small estuary in the vicinity of Port Royal Sound and St. Helena Sound estuaries in South Carolina (SC).

\begin{tabular}{|c|c|c|c|c|c|c|}
\hline $\begin{array}{l}\text { Year } \\
\text { class }\end{array}$ & Tag no. & $\begin{array}{c}\text { Release } \\
\text { date }\end{array}$ & $\begin{array}{c}\text { Recapture } \\
\text { date }\end{array}$ & $\begin{array}{l}\text { Recapture } \\
\text { location }\end{array}$ & $\begin{array}{c}\text { Days at } \\
\text { large }\end{array}$ & $\begin{array}{l}\text { Distance } \\
\quad(\mathrm{km})\end{array}$ \\
\hline 2004 & M0562 & 05/11/05 & 05/27/05 & Port Royal Sound & 16 & - \\
\hline 2004 & M1472 & $05 / 11 / 05$ & 05/28/05 & Port Royal Sound & 17 & 10.0 \\
\hline 2004 & M1382 & $05 / 11 / 05$ & 06/09/05 & Port Royal Sound & 29 & 10.0 \\
\hline 2004 & M1397 & $05 / 11 / 05$ & 06/09/05 & Port Royal Sound & 29 & 10.0 \\
\hline 2004 & M1434 & $05 / 11 / 05$ & 06/12/05 & Port Royal Sound & 32 & - \\
\hline 2004 & M1477 & $05 / 11 / 05$ & 08/25/05 & Port Royal Sound & 106 & 11.6 \\
\hline 2004 & M1326 & $05 / 11 / 05$ & $05 / 16 / 06$ & Port Royal Sound & 370 & - \\
\hline 2005 & M2079 & 05/03/06 & 05/07/06 & Port Royal Sound & 4 & 0.0 \\
\hline 2005 & M2245 & $04 / 27 / 06$ & $05 / 02 / 06$ & Port Royal Sound & 5 & 12.2 \\
\hline 2005 & M2082 & 05/03/06 & 05/10/06 & Port Royal Sound & 7 & 11.0 \\
\hline 2005 & M2357 & 05/03/06 & 05/10/06 & Port Royal Sound & 7 & 11.0 \\
\hline 2005 & M2360 & 05/03/06 & 05/10/06 & Port Royal Sound & 7 & 10.0 \\
\hline 2005 & M2327 & $05 / 08 / 06$ & $05 / 16 / 06$ & Port Royal Sound & 8 & 10.0 \\
\hline 2005 & M2282 & 04/27/06 & 05/06/06 & Port Royal Sound & 9 & 10.0 \\
\hline 2005 & M2081 & 05/03/06 & $05 / 12 / 06$ & Port Royal Sound & 9 & 9.3 \\
\hline 2005 & M2227 & 05/03/06 & $05 / 12 / 06$ & Port Royal Sound & 9 & 12.2 \\
\hline 2005 & M2310 & 05/08/06 & 05/17/06 & - & 9 & - \\
\hline 2005 & M2089 & $05 / 03 / 06$ & 05/13/06 & Port Royal Sound & 10 & 11.0 \\
\hline 2005 & M2234 & 04/27/06 & 05/08/06 & Port Royal Sound & 11 & 11.0 \\
\hline 2005 & M2239 & 04/27/06 & 05/08/06 & - & 11 & - \\
\hline 2005 & M2321 & $05 / 08 / 06$ & $05 / 20 / 06$ & Port Royal Sound & 12 & 10.0 \\
\hline 2005 & M2018 & 04/27/06 & 05/10/06 & Port Royal Sound & 13 & 0.0 \\
\hline 2005 & M2091 & 05/03/06 & $05 / 17 / 06$ & Port Royal Sound & 14 & 11.0 \\
\hline 2005 & M2132 & 05/03/06 & 05/17/06 & Port Royal Sound & 14 & - \\
\hline 2005 & M2155 & 05/03/06 & $05 / 17 / 06$ & Port Royal Sound & 14 & 11.0 \\
\hline 2005 & M2205 & 05/03/06 & $05 / 17 / 06$ & Port Royal Sound & 14 & 10.0 \\
\hline 2005 & M2285 & $05 / 08 / 06$ & $05 / 22 / 06$ & Port Royal Sound & 14 & 11.0 \\
\hline 2005 & M2024 & $04 / 27 / 06$ & $05 / 12 / 06$ & Port Royal Sound & 15 & 10.0 \\
\hline 2005 & M2210 & 05/03/06 & $05 / 19 / 06$ & Port Royal Sound & 16 & 11.0 \\
\hline
\end{tabular}

outside of the stocked area ( 3 in SC and 2 in Florida); however, these fish were recaptured either outside of the spawning season (September-October) or just before or at the onset of the spawning season (early May). Although the sample sizes for recaptures at large for at least one year were small $(n=13)$, all of the recaptures during the spawning season $(n=8)$ occurred within the inshore vicinity of the stocked estuary.

\section{Population structure}

On the basis of the 2008 samples, pairwise comparisons of both genotypic distributions and hierarchical $R_{\mathrm{ST}}$ values indicated no differences among the offshore collection locations ( $G$-test: $P=0.075, R_{\mathrm{ST}}=0.005$, $P=0.14$; Table 6). However, the two inshore collection locations were significantly different from both each other ( $G$-test: $\left.P<0.001 ; R_{\mathrm{ST}}: 0.043, P<0.001\right)$ and from the homogenous offshore group ( $G$-test:
$\left.P<0.001 ; R_{\mathrm{ST}}: 0.011-0.023, P<0.05\right)$; with the exception of the inshore VA and offshore NC collection locations. The AMOVA results were consistent with this pattern, showing significant differences among populations $(1.6 \%, P<0.001$, Table 7$)$ and the highest proportion of among-group molecular variation (1.3\%) when grouped according to the pair-wise results. Results derived from the 2009 samples were concordant with the patterns detected in 2008 (AMOVA: $1.2 \%, P<0.001 ; 2.3 \%$ among groups), with the SC inshore collection being significantly different ( $G$-test: $\left.P<0.001 ; R_{\mathrm{ST}}: 0.017-0.018, P<0.009\right)$ from the homogenous NC and SC offshore group ( $G$-test: $P=0.53$; $R_{\mathrm{ST}}=0.006, P=0.16$; Table 8 ). Results from use of the Structure software for both collection years supported the pairwise and AMOVA patterns of genetic differentiation (Fig. 2). On the basis of trajectories of both Ln probabilities and variance metrics, $k$ (number of populations) was estimated at 3 populations for the 2008 


\begin{tabular}{|c|c|c|c|c|c|c|}
\hline \multicolumn{7}{|c|}{ Table 5 (continued) } \\
\hline 2005 & M2211 & 05/03/06 & 05/19/06 & Port Royal Sound & 16 & 11.0 \\
\hline 2005 & M2028 & 04/27/06 & $05 / 14 / 06$ & St. Helena Sound & 17 & 62.0 \\
\hline 2005 & M2102 & $05 / 03 / 06$ & $05 / 20 / 06$ & - & 17 & - \\
\hline 2005 & M2086 & 05/03/06 & $05 / 21 / 06$ & Port Royal Sound & 18 & 11.0 \\
\hline 2005 & M2107 & $05 / 03 / 06$ & $05 / 21 / 06$ & Port Royal Sound & 18 & 11.0 \\
\hline 2005 & M2146 & 05/03/06 & $05 / 21 / 06$ & Port Royal Sound & 18 & 11.0 \\
\hline 2005 & M2007 & $04 / 27 / 06$ & 05/16/06 & Port Royal Sound & 19 & 11.0 \\
\hline 2005 & M2187 & $05 / 03 / 06$ & $05 / 22 / 06$ & Port Royal Sound & 19 & 11.0 \\
\hline 2005 & M2005 & $04 / 27 / 06$ & 05/17/06 & Port Royal Sound & 20 & 11.0 \\
\hline 2005 & M2042 & 04/27/06 & 05/17/06 & Port Royal Sound & 20 & 11.0 \\
\hline 2005 & M2002 & $04 / 27 / 06$ & $05 / 19 / 06$ & Port Royal Sound & 22 & 11.0 \\
\hline 2005 & M2232 & 04/27/06 & 05/19/06 & Port Royal Sound & 22 & 11.0 \\
\hline 2005 & M2016 & $04 / 27 / 06$ & $05 / 21 / 06$ & Port Royal Sound & 24 & - \\
\hline 2005 & M2039 & $04 / 27 / 06$ & $05 / 21 / 06$ & Port Royal Sound & 24 & - \\
\hline 2005 & M2163 & $05 / 03 / 06$ & $05 / 29 / 06$ & - & 26 & - \\
\hline 2005 & M2223 & $05 / 03 / 06$ & $05 / 29 / 06$ & - & 26 & - \\
\hline 2005 & M2241 & $04 / 27 / 06$ & $05 / 24 / 06$ & Port Royal Sound & 27 & - \\
\hline 2005 & M2068 & $05 / 03 / 06$ & 06/05/06 & - & 33 & - \\
\hline 2005 & M2141 & 05/03/06 & $06 / 05 / 06$ & St. Helena Sound & 33 & 54.7 \\
\hline 2005 & M2015 & $04 / 27 / 06$ & 06/02/06 & Port Royal Sound & 36 & 11.0 \\
\hline 2005 & M2027 & $04 / 27 / 06$ & 06/02/06 & Port Royal Sound & 36 & 11.0 \\
\hline 2005 & M2242 & $04 / 27 / 06$ & 06/06/06 & Port Royal Sound & 40 & 11.0 \\
\hline 2005 & M2377 & 05/03/06 & $05 / 05 / 07$ & Charleston Harbor & 367 & 123.9 \\
\hline 2005 & M2249 & 05/03/06 & 09/15/07 & Offshore SC & 500 & 65.5 \\
\hline 2005 & M2131 & 05/03/06 & $05 / 20 / 08$ & Port Royal Sound & 748 & 11.0 \\
\hline 2005 & M2238 & $04 / 27 / 06$ & $05 / 20 / 08$ & Calibogue Sound & 754 & 44.3 \\
\hline 2005 & M2017 & $04 / 27 / 06$ & $05 / 25 / 08$ & Port Royal Sound & 759 & 20.6 \\
\hline 2005 & M2281 & $04 / 27 / 06$ & $05 / 30 / 08$ & Port Royal Sound & 764 & 11.0 \\
\hline 2005 & M217? & $05 / 03 / 06$ & $06 / 18 / 08$ & Port Royal Sound & 777 & 20.0 \\
\hline 2005 & M2046 & $04 / 27 / 06$ & $06 / 18 / 08$ & Port Royal Sound & 783 & 20.0 \\
\hline 2005 & M2197 & 05/03/06 & $10 / 03 / 08$ & Offshore SC & 884 & 77.2 \\
\hline 2005 & M2118 & $05 / 03 / 06$ & $05 / 11 / 09$ & Offshore FL & 1104 & 241.4 \\
\hline 2005 & M2387 & $05 / 03 / 06$ & $05 / 15 / 09$ & Port Royal Sound & 1108 & 11.0 \\
\hline 2005 & M2265 & 05/03/06 & 09/14/09 & St. Mary's River, FL & 1230 & 207.6 \\
\hline 2005 & M2004 & 04/27/06 & - & - & - & - \\
\hline 2005 & M2051 & 05/03/06 & - & - & - & - \\
\hline
\end{tabular}

\section{Table 6}

Summary of results for the comparision of genotypic distribution ( $P$-values below diagonal) and $R_{\mathrm{ST}}$ pairwise (above diagonal) location from the 2008 sample collections of Cobia (Rachycentron canadum). Collection locations included inshore Virginia (VA), offshore North Carolina $\left(\mathrm{NC}_{\mathrm{Off}}\right)$, and offshore South Carolina $\left(\mathrm{SC}_{\mathrm{Off}}\right)$, and inshore South Carolina (SC). Bold type indicates statistical significance after Bonferroni correction (critical $P=0.008$ ).

\begin{tabular}{ccccc}
\hline & $\mathrm{VA}$ & $\mathrm{NC}_{\text {Off }}$ & $\mathrm{SC}_{\text {Off }}$ & $\mathrm{SC}$ \\
\hline $\mathrm{VA}$ & - & 0.001 & $\mathbf{0 . 0 1 1}$ & $\mathbf{0 . 0 4 3}$ \\
$\mathrm{NC}_{\text {Off }}$ & 0.013 & - & 0.005 & $\mathbf{0 . 0 2 3}$ \\
$\mathrm{SC}_{\text {Off }}$ & $<\mathbf{0 . 0 0 1}$ & 0.075 & - & $\mathbf{0 . 0 1 6}$ \\
$\mathrm{SC}$ & $<\mathbf{0 . 0 0 1}$ & $<\mathbf{0 . 0 0 1}$ & $<\mathbf{0 . 0 0 1}$ & - \\
& & & & \\
\hline
\end{tabular}

collection and 2 populations for the 2009 collections. Consistent with the low $R_{\mathrm{ST}}$ estimates, the results from the Structure software indicated the presence of mixed ancestry among these populations.

Temporal within-location comparisons of the 2008 and 2009 collections showed no significant differences in genetic compositions ( $G$-test: $P=0.51-0.56$; $R_{\mathrm{ST}}<0.006, P>0.016$ ), validating the pooling of samples across collection years for population characterization. Basic molecular diversity indices were similar among collection locations, with high levels of genetic diversity across all loci and high levels of polymorphism (Table 9). The mean number of alleles per locus ranged from 10.4 to 14.0 (average allelic range: $14.5-16.4$ ). The overall average observed heterozygosity for Cobias was moderate and ranged from 0.709 in the SC inshore collection to 0.772 in the VA inshore collection, with the $\mathrm{NC}$ and SC offshore collections showing intermediate 


\section{Table 7}

Summary of analysis of molecular variance (AMOVA) indicating partitioning of genetic variation on the basis of our 2008 (top) and 2009 (bottom) sample collections of Cobia (Rachycentron canadum) in South Carolina. $\mathrm{df}=$ degrees of freedom.

\begin{tabular}{llrrrrr}
\hline $\begin{array}{l}\text { Collection } \\
\text { year }\end{array}$ & Source of variation & df & $\begin{array}{c}\text { Sum of } \\
\text { squares }\end{array}$ & $\begin{array}{c}\text { Variance } \\
\text { component }\end{array}$ & $\begin{array}{c}\text { Percentage } \\
\text { of variation }\end{array}$ & $P$-value \\
\hline 2008 & Among populations & 3 & 973 & 1.6 & 1.6 & $<0.0001$ \\
& Within populations & 594 & 56,980 & 95.9 & 98.4 & \\
& Total & 597 & 57,953 & 97.5 & & \\
\multirow{2}{*}{2009} & Among populations & 2 & 473 & 1.1 & 1.2 & $<0.0001$ \\
& Within populations & 437 & 37,760 & 86.4 & 98.8 & \\
& Total & 439 & 38,233 & 87.5 & &
\end{tabular}

diversity. Inbreeding was low $\left(P>0.21 ; F_{\text {IS }}<0.07\right)$ in all collection locations.

\section{Discussion}

In recent years, SCDNR has expanded the use of genetic tools to identify many types of stocked fish, specifically Red Drum (Sciaenops ocellatus), Striped Bass (Morone saxatilis), and Spotted Seatrout (Cynoscion nebulosus), and to characterize their genetic population structure. These tools create permanently identifiable tags with the use of microsatellite markers that are useful for genetically characterizing fish populations. South Carolina's Cobia research program is the first to begin rigorously evaluating U.S. populations from a genetic perspective. On the basis of our U.S. collections of Cobias encountered along the south Atlantic coast, tests of both genotypic distributions and pairwise hierarchical $R_{\mathrm{ST}}$ statistics indicate that the offshore groups are genetically homogenous, a finding

\section{Table 8}

Results of the genotypic distribution ( $P$-values below diagonal) and $R_{\text {ST }}$ pair-wise (above diagonal) comparisons of locations from the 2009 sample collections of Cobia (Rachycentron canadum). Collection locations were offshore North Carolina $\left(\mathrm{NC}_{\mathrm{Off}}\right)$, offshore South Carolina ( $\mathrm{SC}_{\mathrm{Off}}$ ), and inshore South Carolina (SC). Bold type indicates statistical significance following Bonferroni correction (critical $P=0.017$ ).

\begin{tabular}{cccc}
\hline & $\mathrm{NC}_{\text {Off }}$ & $\mathrm{SC}_{\text {Off }}$ & $\mathrm{SC}$ \\
\hline $\mathrm{NC}_{\text {Off }}$ & - & 0.006 & $\mathbf{0 . 0 1 7}$ \\
$\mathrm{SC}_{\text {Off }}$ & 0.529 & - & $\mathbf{0 . 0 1 8}$ \\
$\mathrm{SC}$ & $<\mathbf{0 . 0 0 1}$ & $<\mathbf{0 . 0 0 1}$ & - \\
& & &
\end{tabular}

that is consistent with Hrincevich's (1993) findings. However, the detection of the two genetically distinct inshore aggregations ( $\mathrm{SC}$ and VA) is new information in our understanding of Cobia life history. Although a significant degree of genetic isolation was detected among these inshore aggregations and the offshore group, the low $R_{\mathrm{ST}}$ statistics and the mixed ancestry patterns indicate that a low level of gene flow does occur.

We recognize that population structure can be easily masked by a mixed stock effect, whereby gene flow is limited among population groups by different spawning behaviors, yet intermingling occurs outside of the spawning period. For example, if populations of fish spawn in unique locations but intermingle and migrate with other populations during the nonspawning season, the composition of nonspawning breeding stocks would appear to be homogenous in terms of allele frequency distributions, whereas gene flow would be restricted to individuals spawning at each unique spawning site. Only sampling of spawning individuals at each unique spawning site would reveal the true genetic structure. Although we have temporally limited our sampling to the spawning period of Cobia, it is possible that the lack of detected genetic differences between the VA inshore aggregation and the NC offshore samples is due to confounding effects of the potential migration patterns of Cobia. In a migrating species, the logistics of sampling individuals in one location without resampling from the same group in another location is challenging. Although temporally limiting sampling can lessen the confounding effects of such migrations on evaluations of population genetics, in the case of Cobias, the limited period of accessibility for sampling coincides with both their spawning season as well as their proposed northward migration. Therefore, although our sampling was temporally limited, it is possible that VA individuals were present among the Cobias collected offshore of $\mathrm{NC}$ as they were completing their migration to the VA inshore aggregation. 


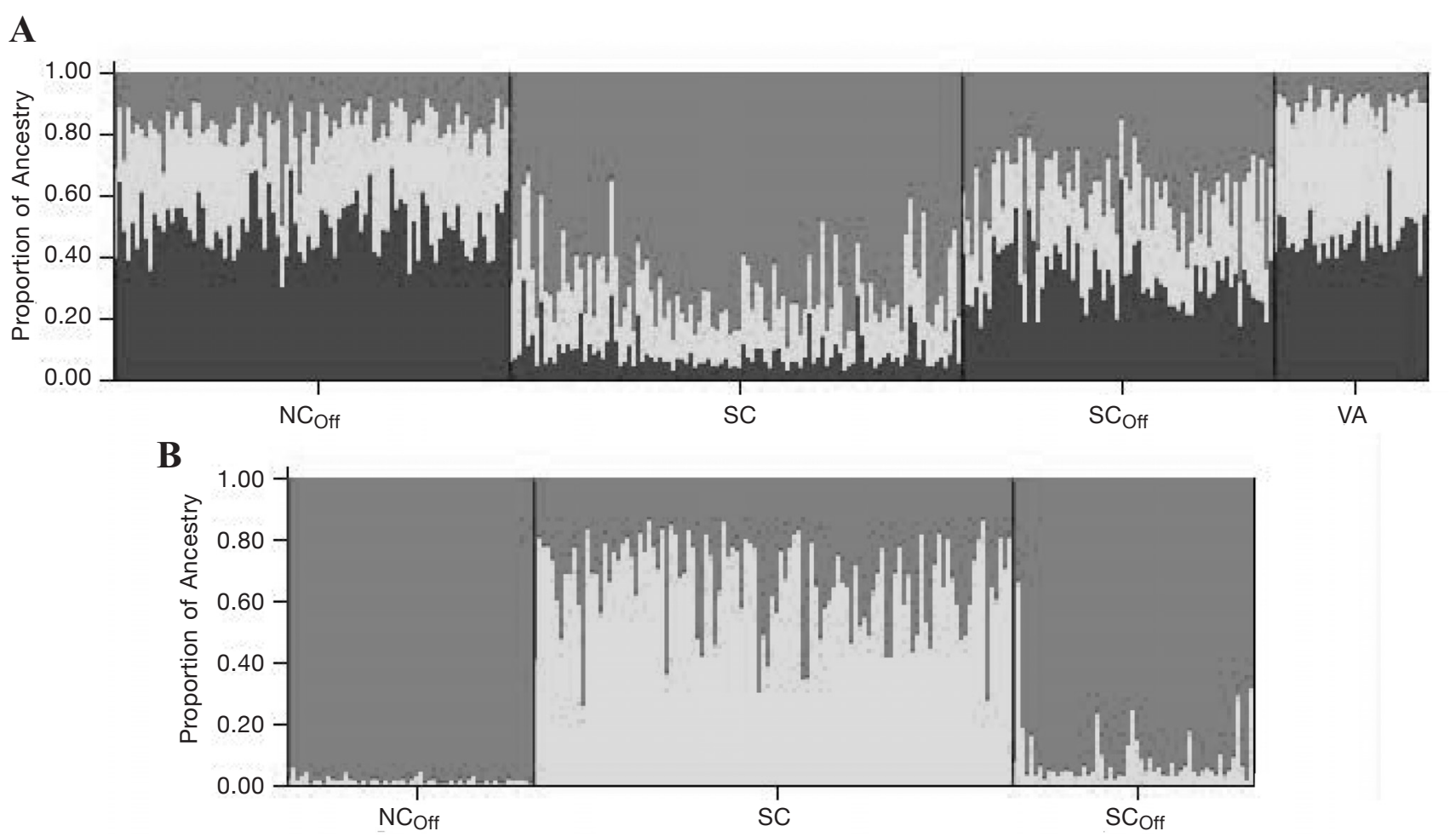

Figure 2

Results of genetic analyses with the use of Structure software for (A) the 2008 and (B) 2009 collections of Cobia (Rachycentron canadum), where each column represents an individual sample and the shades of gray represent the ancestral populations. Multiple shades within a column indicate an individual of mixed ancestry. Collection locations are grouped together and are the following: offshore North Carolina $\left(\mathrm{NC}_{\mathrm{Off}}\right)$, inshore South Carolina $(\mathrm{SC})$, offshore South Carolina ( $\left.\mathrm{SC}_{\mathrm{Off}}\right)$, and inshore Virginia (VA).

The genesis of Cobia research in SC began with the need to collect life history information to explore the potential of this species for aquaculture production and to better understand the impact stocking

\section{Table 9}

Summary of genetic diversity statistics pooled across collection years for Cobia (Rachycentron canadum). Collection locations included inshore Virginia (VA), offshore North Carolina $\left(\mathrm{NC}_{\mathrm{Off}}\right)$, inshore South Carolina (SC), and offshore South Carolina $\left(\mathrm{SC}_{\mathrm{Off}}\right) . n=$ sample size, $\mathrm{N}_{\mathrm{A}}=$ average number of alleles per locus, $H_{\mathrm{O}}=$ average observed heterozygosity across loci, $H_{\mathrm{E}}=$ average expected heterozygosity across loci, $F_{\mathrm{IS}}=$ inbreeding coefficient.

\begin{tabular}{lrrrrr}
\hline Collection location & $n$ & $\mathrm{~N}_{\mathrm{A}}$ & $H_{\mathrm{O}}$ & $H_{\mathrm{E}}$ & $F_{\text {IS }}$ \\
\hline $\mathrm{VA}$ & 35 & 10.4 & 0.772 & 0.768 & 0.07 \\
$\mathrm{NC}_{\text {Off }}$ & 146 & 14.0 & 0.762 & 0.757 & -0.01 \\
$\mathrm{SC}$ & 212 & 11.5 & 0.709 & 0.717 & -0.03 \\
$\mathrm{SC}_{\text {Off }}$ & 126 & 12.7 & 0.745 & 0.753 & -0.05 \\
& & & & &
\end{tabular}

may have on a highly migratory species. The scope of our program not only encompassed gathering information on basic life history and population dynamics from the wild population, but also incorporated information on tagged stocked animals to better understand movement patterns and fidelity to natal estuaries. Collection of such information has proven to be useful for interpreting genetic results. The detection of stocked fish from multiple year classes of fish released within the Port Royal Sound estuary was somewhat unexpected given the many unknowns regarding Cobia life history (e.g., their use of juvenile habitat, their home ranges, movement patterns, and spawning migrations). Although the initial 1.1\% contribution to the $2004 \mathrm{YC}$ appears low, when considering the limited number of fish originally released, we interpreted these results as being pos- 
itive in terms of the potential for stock enhancement to be effective as a fisheries management tool for Cobia. The results show how understanding life history attributes is necessary to designing a stocking program for a highly migratory pelagic species. The much higher stocking contribution observed in 2009 following the larger 2007 YC release during their first year of potential recruitment to the fishing gear provides additional support for the efficacy of stock enhancement. Furthermore, the recapture of these stocked fish within their release estuary two years after release indicates that some degree of estuarine fidelity occurs within these inshore Cobia aggregations, supporting the identification of the unique genetic structure in wild fish populations. Estuarine fidelity is also indicated by the recapture of an individual wild fish within the Port Royal Sound estuary during multiple collection years; as well as by the high incidence of external tag recapture reports occurring within the Port Royal Sound area. Therefore, these results complement both the previously observed high site fidelity in SC (Hammond ${ }^{3}$ ) and Lefebvre and Denson's (2012) documented spawning function of the inshore aggregations on the basis of positive Cobia egg and larval detection within the Port Royal Sound estuary.

In the Persian Gulf and Oman Sea, Salari Aliabadi et al. (2008) also investigated small-scale population structure in Cobias, using microsatellite markers. Although they reported the presence of 3 distinct genetic populations along their northern coasts, their study was likely confounded by small sample sizes, lack of a temporal sampling design, and no corrections for multiple comparisons in their analyses as they were unable to identify any potential behavioral or geographic mechanisms of genetic isolation among detected groupings. In contrast, we used robust sampling and analysis approaches that provided links between the detected genetic structure and the several indications of mechanisms of genetic isolation (seasonal aggregations and estuarine fidelity).

\section{Conclusions}

The genetic diversity, in terms of both gene diversity and allelic richness, detected in Cobias along the southeastern U.S. Atlantic coast is similar to that reported in both Iran (Salari Aliabadi et al., 2008) and the northern Gulf of Mexico (Pruett et al., 2005), and all metrics are somewhat higher than the averages reported for marine fishes (DeWoody and Avise, 2000). Therefore, on the basis of the genetic characterization

\footnotetext{
${ }^{3}$ Hammond, D. 2001. Status of the South Carolina fishery for cobia. South Carolina Department of Natural Resources Technical Report Number 89, 22 p. [Available from the Office of Fisheries Management, Marine Resources Division, South Carolina Department of Natural Resources, P.O. Box 12559, Charleston, SC 29422-2559.]
}

along the southeastern Atlantic coast of the United States, Cobia appears to be quite genetically diverse both overall and within localized areas and exhibits temporal stability over the project period. However, the detection of discrete genetic structure for Cobia within this portion of its range has implications for the appropriate management of this important recreational fisheries species.

As with many aspects of Cobia's life history, the implications of our genetic results for management are not straightforward. For example, information gathered from the offshore collections shows high levels of movement along the southeastern U.S. Atlantic, and a recommendation founded only on that observation might include continuation of the single population management strategy because overfishing in one offshore area would affect other areas as well. In contrast, a recommendation made solely on the basis of the inshore collections that indicate the presence of distinct population segments and estuarine fidelity in Cobia might favor separate management of the population segments because localized fishing pressure would primarily impact the local population. However, perhaps given the complicated life history of the Cobia, a more appropriate recommendation would be to use a 2 -tiered strategy, in which Cobias are managed regionally as a single population for offshore fishery activities, but are also managed at the local level (state management) for aggregation-specific inshore fishing activities. Considering the genetic uniqueness of the inshore aggregations, there is concern that the majority of the fishing pressure on these aggregations targets the reproductive pool of Cobia on their spawning grounds. Although there is still much to learn about the intricacies of Cobia life history, the results presented here are needed for informed decisions regarding the future management of this recreationally and commercially important species.

\section{Acknowledgments}

The authors wish to thank the charter boat captains and cooperating fishermen in VA, NC, SC, and Florida who provided genetic samples and reported external tags-for their efforts without which we would not have been able to complete this research. We also thank L. Borecki, B. Cushman, D. Farrae, M. Jamison, W. Jenkins, L. Lefebvre, B. McAbee, M. Perkinson, and C. Tarpey for providing invaluable assistance and comments on this project. We appreciate the cooperation of M. Renshaw and J. Gold during our initial project work. Our work was funded in part by the South Carolina Department of Natural Resources and grant no. 114775-GL10013 (grant in aid no. NA16RG1646) from the National Marine Aquaculture Initiative of the National Oceanic and Atmospheric Administration. This publication is number 692 from the Marine Resources Research Institute. 


\section{Literature cited}

Brown-Peterson, N. J., R. M. Overstreet, J. M. Lotz, J. S. Franks, and K. M. Burns.

2001. Reproductive biology of cobia, Rachycentron canadum, from coastal waters of the southern United States. Fish. Bull. 99:15-28.

Danzmann, R. G.

1997. Probmax: a computer program for assigning unknown parentage in pedigree analysis from known genotypic pools of parents and progeny. J. Hered. 88:333.

DeWoody, J. A., and J. C. Avise.

2000. Microsatellite variation in marine, freshwater, and anadromous fishes compared to other animals. J. Fish. Biol. 56:461-473.

Excoffier L., G. Laval, and S. Schneider.

2005. Arlequin (version 3.0): an integrated software package for population genetics data analysis. Evol. Bioinformatics Online 1:47-50.

Hassler, W. W., and R. P. Rainville.

1975. Techniques for hatching and rearing cobia, Rachycentron canadum, through larval and juvenile stages. Sea Grant College Prog. Rep. UNC-SC-75-30, 26 p. Univ. North Carolina, Raleigh, NC.

Hrincevich, A. W.

1993. Mitochondrial DNA analysis of cobia Rachycentron canadum population structure using restriction fragment length polymorphisms and cytochrome $\mathrm{b}$ sequence variation. M.S. thesis, 92 p. Univ. Southern Mississippi, Hattiesburg, MS.

Joseph, E. B., J. J. Norcross, and W. H. Massmann.

1964. Spawning of the cobia, Rachycentron canadum, in the Chesapeake Bay Area, with observations of juvenile specimens. Chesapeake Sci. 5:67-71.

Kalinowski, S. T., M. L. Taper, and T. C. Marshall.

2007. Revising how the computer program CERVUS accommodates genotyping error increases success in paternity assignment. Mol. Ecol. 16:1099-1006.

Lefebvre, L. S., and M. R. Denson.

2012. Inshore spawning of cobia. (Rachycentron canadum) in South Carolina. Fish. Bull. 110:397-412.

Lotz, J. M., R. M. Overstreet, and J. S. Franks.

1996. Gonadal maturation in the cobia, Rachycentron canadum, from the northcentral Gulf of Mexico. Gulf Res. Rep. 9:147-159.

McGlade, M.

2007. Cobia at the Chesapeake. Virginia Wildlife 68 : $12-16$.

Nei, M.

1987. Molecular evolutionary genetics, 512 p. Columbia Univ. Press, New York.
Pritchard, J. K., M. Stephens, and P. Donnelly.

2000. Inference of population structure using multilocus genotype data. Genetics 155:945-959.

Pruett, C. L., E. Saillant, M. A. Renshaw, J. C. Patton, C. E. Rexroad III, and J. R. Gold.

2005. Microsatellite DNA markers for population genetic studies and parentage assignment in cobia, Rachycentron canadum. Mol. Ecol. Notes 5:84-86.

Raymond, M., and F. Rousset.

1995. Genepop (version 1.2): population genetics software for exact tests and ecumenicism. J. Hered. 86:248-249.

Renshaw, M. A., E. Saillant, S. C. Bradfield, and J. R. Gold. 2006. Microsatellite multiplex panels for genetic studies of three species of marine fishes: red drum (Sciaenops ocellatus), red snapper (Lutjanus campechanus), and cobia (Rachycentron canadum). Aquaculture 253:731-735.

Rice, W. R.

1989. Analyzing tables of statistical tests. Evolution 43:223-225.

Richards, C. E.

1967. Age, growth, and fecundity of the cobia, Rachycentron canadum, from Chesapeake Bay and adjacent midAtlantic waters. Trans. Am. Fish. Soc. 96:343-350.

Salari Aliabadi, M. A., S. Rezvani Gilkolaei, A. Savari, H. Zolgharnein, and S. M. B. Nabavi.

2008. Microsatellite polymorphism in Iranian populations of cobia (Rachycentron canadum G.). Biotechnology 7:775-780.

Shaffer, R. V., and E. L. Nakamura.

1989. Synopsis of biological data on the cobia Rachycentron canadum. Pisces: Rachycentridae. NOAA Tech. Rep. NMFS 82 (FAO Fisheries Synopsis 153), 21 p.

Slatkin, M.

1995. A measure of population subdivision based on microsatellite allele frequencies. Genetics 139:457-462.

Smith, J. W.

1995. Life history of cobia, Rachycentron canadum (Osteichthyes: Rachycentridae), in North Carolina. Brimleyana 23:1-23.

Taggart, J. B.

2007. FAP: an exclusion-based parental assignment program with enhanced predictive functions. Mol. Ecol. Notes 7:412-415.

Weirich, C. R., T. I. J. Smith, M. R. Denson, A. D. Stokes, and W. E. Jenkins.

2004. Pond rearing of larval and juvenile cobia, Rachycentron canadum, in the southeastern United States: initial observations. J. Appl. Aquacult. 16:27-44. 